\title{
Cadmium Accumulation Characteristics of Cyphomandra betacea Seedlings
}

\author{
Mei Qing ${ }^{1, a}$, Lijin Lin²,b and Ming'an Liao, c* \\ ${ }^{1}$ College of Horticulture, Sichuan Agricultural University, Chengdu, Sichuan, China \\ ${ }^{2}$ Institute of Pomology and Olericulture, Sichuan Agricultural University, Chengdu, Sichuan, China \\ a1115435013@qq.com, bllj800924@qq.com, 9man@sicau.edu.cn \\ ${ }^{*}$ Corresponding author. Mei Qing and Lijin Lin contributed equally to this work.
}

\begin{abstract}
Keywords: Cyphomandra betacea; Cadmium; Accumulation Characteristics
Abstract: A pot experiment was conducted to study the accumulation characteristics of cadmium (Cd) in Cyphomandra betacea Seedlings. The annual $C$. betacea seedlings were treated with Cd of different concentration gradients $(0-20 \mathrm{mg} / \mathrm{kg})$. The results showed that with the increase of soil $\mathrm{Cd}$ concentration, the root biomass, stem biomass, leaf biomass and shoot biomass of $C$. betacea seedlings tended to decrease, without showing obvious toxic symptoms. When the soil $\mathrm{Cd}$ concentration was less than $5 \mathrm{mg} / \mathrm{kg}$, the distribution of $\mathrm{Cd}$ in C. betacea seedlings was as follows: root $>$ stem $>$ shoot $>$ leaf, when the Cd concentration in soil was more than $5 \mathrm{mg} / \mathrm{kg}$, the order of $\mathrm{Cd}$ content in the organs of $C$. Betacea seedlings was: root $>$ leaf $>$ shoot $>$ stem. With the increase of soil $\mathrm{Cd}$ concentration, the $\mathrm{Cd}$ content in $C$. betacea seedlings increased evidently, when the soil $\mathrm{Cd}$ concentration reached $20 \mathrm{mg} / \mathrm{kg}$, the Cd content in the roots was $168.86 \mathrm{mg} / \mathrm{kg}$, and $8.08 \mathrm{mg} / \mathrm{kg}$ in the shoots respectively. For the translocation factor (TF), the results showed that the TF of $C$. Betacea seedlings decreased first and then increased, and the TF of different soil Cd concentration was less than 0.3 . Therefore, with $\mathrm{Cd}$ accumulated mainly in the roots, $C$. betacea seedlings had a strong tolerance to Cd stress.
\end{abstract}

\section{Introduction}

Cadmium $(\mathrm{Cd})$ is a natural element in the earth's crust, and is one of the most toxic heavy metals which can be a serious threat to human health [1]. With the development of industry and agriculture, the contaminated area of heavy metal in soil is increasing [2]. In response to Cd stress in plant seedlings, previous studies showed that low concentration of $\mathrm{Cd}$ might promote the growth, and as the concentration of $\mathrm{Cd}$ increased, the biomass, the content of chlorophyll, and the activity of antioxidant enzyme decreased, which were detrimental to plant growth $[3,4]$. The results of fluorescence quantitative PCR showed that plants could remove reactive oxygen from Cd stress by synergistic action of antioxidant enzymes and non-enzymatic substances in the body [5]. However,there are significant differences in the distrubution and tolerance of different plants to $\mathrm{Cd}$ tress and different plants have different detoxification mechanisms against Cd stress [6]. Cyphomandra betacea is a fruit tree belongs to the Solanaceae family, and is currently cultivated in the southwest part of China [7]. Other researchers have found that C. betacea had strong ability to resist insect pests and could grow normally under low concentration Cd pollution $(10 \mathrm{mg} / \mathrm{kg})[7,8]$. To further understand the $\mathrm{Cd}$ accumulation characteristics of $C$. betacea seedlings, a pot experiment with $\mathrm{Cd}$ of different concentration gradients $(0-20 \mathrm{mg} / \mathrm{kg})$ was conducted. The objectives of this study were to provide guiding significance for its cultivation application and safe production in $\mathrm{Cd}$ contaminated orchard.

\section{Materials and Methods}

Materials. The seeds of $C$. betacea were collected from a perennial $C$. betacea of Chengdu Academy of Agriculture and Forestry $\left(30^{\circ} 42^{\prime} \mathrm{N}, 103^{\circ} 51^{\prime} \mathrm{E}\right)$ in August, 2016, air-dried and stored at $4{ }^{\circ} \mathrm{C}$ respectively. 
Experimental Design. The experiment was conducted at Chengdu Campus of Sichuan Agricultural University $\left(30^{\circ} 42^{\prime} \mathrm{N}, 103^{\circ} 51^{\prime} \mathrm{E}\right)$ from May to August 2017. The soil samples were air-dried and passed through a 5-mm mesh in May 2017, and then $3.0 \mathrm{~kg}$ of soil was weighed into each polyethylene pot $(15 \mathrm{~cm}$ tall, $18 \mathrm{~cm}$ diameter). $\mathrm{Cd}$ was added to make a final soil $\mathrm{Cd}$ concentration of $0,1,5,10,15$ and $20 \mathrm{mg} / \mathrm{kg}$. with a saturated heavy metal solution in the form of $\mathrm{CdCl}_{2} \cdot 2.5 \mathrm{H}_{2} \mathrm{O}$. The soils were mixed aperiodically during the next 4 weeks, and the soil moisture was kept at $80 \%$. The seeds of $C$. betacea were sown in the farmland of the Chengdu Campus in June 2017. Two weeks later, three seedlings of each treatment were transplanted into each pot, and each treatment was repeated five times with a $10-\mathrm{cm}$ spacing between pots. In order to reduce the marginal effect, the position of the pots was completely randomly arranged and exchanged during the whole growth process. After 2 months of planting, the whole plant was harvested, washed with tap water and detached water for 3 times. The sample of tree tomato was divided into three parts: root, stem and leaf, each part was killed at $75{ }^{\circ} \mathrm{C}$ for 15 min.and dried at $110{ }^{\circ} \mathrm{C}$ for $15 \mathrm{~min}$. Electronic balance was used to weigh the biomass of the samples. After boiling with nitroacid and hyperchloric acid (volume product ratio 4: 1), iCAP6300 type ICP spectrometer was used to determine the $\mathrm{Cd}$ content and translocation factor $(\mathrm{TF}), \mathrm{TF}=\mathrm{Cd}$ content in shoots/ $\mathrm{Cd}$ content in roots [9].

Statistical Analyses. Statistical analyses were conducted using SPSS 17.0 statistical software (IBM, Chicago, IL, USA). Data were analyzed by one-way analysis of variance with least significant difference (LSD) at the $\mathrm{p}=0.05$ confidence level.

\section{Results and Discussion}

Biomass of $\boldsymbol{C}$. betacea seedlings. The order of organ biomass of $C$. betacea seedlings was: leaf > root $>$ stem, and the shoot biomass was 4 times bigger than the root biomass (Table 1). The biomass of $C$. betacea seedlings under soil Cd concentration of $1 \mathrm{mg} / \mathrm{kg}$ was the same as that of the control, but with the increase of soil $\mathrm{Cd}$ concentration, the root biomass, the stem biomass and the leave biomass tended to decrease. Under soil Cd concentration of $1,5,10,15$ and $20 \mathrm{mg} / \mathrm{kg}$, the root biomass decreased by $4.04 \%(P>0.05), 5.56 \%(P>0.05), 8.59 \%(P<0.05), 10.10 \%(P<0.05)$ and $27.27 \%(P<0.05)$ respectively, compared with the control. With the increase of soil $\mathrm{Cd}$ concentration, the trends of stem, leaf and shoot biomasses were the same as the root biomass. Under soil Cd concentration of 1, 5, 10, 15 and $20 \mathrm{mg} / \mathrm{kg}$, the stem biomass decreased by $6.43 \%$ $(P>0.05), 24.29 \%(P<0.05), 24.29 \%(P<0.05), 23.57 \%(P<0.05)$ and $33.57 \%(P<0.05)$ respectively, compared with the control, the leave biomass decreased by $-3.17 \%(P>0.05), 6.20 \%$ $(P<0.05), 15.80 \%(P<0.05), 22.48 \%(P<0.05)$ and $36.89 \%(P<0.05)$ respectively, and the shoot biomass decreased by $-1.68 \%(P>0.05), 9.12 \%(P<0.05), 17.17 \%(P<0.05), 22.57 \%(P<$ $0.05)$ and $36.25 \%(P<0.05)$ respectively, compared with the control. Thus, Cd stress could reduce the biomass of $C$. betacea seedlings and inhibit the growth, and with the increase of $\mathrm{Cd}$ concentration, the inhibition increased.

Table 1 The biomass of $C$. betacea seedlings

\begin{tabular}{|c|c|c|c|c|}
\hline $\begin{array}{c}\text { Cd } \\
\text { concentration } \\
(\mathrm{mg} / \mathrm{kg})\end{array}$ & $\begin{array}{c}\text { Roots } \\
\text { (g/plant) }\end{array}$ & $\begin{array}{c}\text { Stems } \\
(\mathrm{g} / \text { plant })\end{array}$ & $\begin{array}{c}\text { leaves } \\
(\mathrm{g} / \mathrm{plant})\end{array}$ & $\begin{array}{c}\text { Shoots } \\
\text { (g/plant) }\end{array}$ \\
\hline 0 & $0.198 \pm 0.001 \mathrm{a}$ & $0.140 \pm 0.005 \mathrm{a}$ & $0.694 \pm 0.001 \mathrm{a}$ & $0.833 \pm 0.007 \mathrm{a}$ \\
\hline 1 & $0.190 \pm 0.007 \mathrm{a}$ & $0.131 \pm 0.007 \mathrm{a}$ & $0.716 \pm 0.021 \mathrm{a}$ & $0.847 \pm 0.028 \mathrm{a}$ \\
\hline 5 & $0.187 \pm 0.006 \mathrm{ab}$ & $0.106 \pm 0.007 \mathrm{~b}$ & $0.651 \pm 0.023 \mathrm{~b}$ & $0.757 \pm 0.015 \mathrm{~b}$ \\
\hline 10 & $0.181 \pm 0.009 \mathrm{~b}$ & $0.106 \pm 0.006 \mathrm{~b}$ & $0.584 \pm 0.010 \mathrm{c}$ & $0.690 \pm 0.004 \mathrm{c}$ \\
\hline 15 & $0.178 \pm 0.001 \mathrm{~b}$ & $0.107 \pm 0.009 \mathrm{~b}$ & $0.538 \pm 0.006 \mathrm{~d}$ & $0.645 \pm 0.014 \mathrm{~d}$ \\
\hline 20 & $0.144 \pm 0.001 \mathrm{c}$ & $0.093 \pm 0.007 \mathrm{~b}$ & $0.438 \pm 0.007 \mathrm{e}$ & $0.531 \pm 0.013 \mathrm{e}$ \\
\hline
\end{tabular}

Different lowercase letters indicate significant differences based on one-way analysis of variance in SPSS 17.0 followed by the least significant difference test $(P<0.05)$. 
Cd content in $\boldsymbol{C}$. betacea seedlings. Table 2 shows that with the increase of soil $\mathrm{Cd}$ concentration, the content of $\mathrm{Cd}$ in the roots, stems, leaves and shoots of $C$. Betacea seedlings increased, and the difference between each treatment was significant $(P<0.05)$. The distribution of $\mathrm{Cd}$ in $C$. Betacea seedlings was different under different soil $\mathrm{Cd}$ concentration. When the soil $\mathrm{Cd}$ concentration in soil was 0,1 and $5 \mathrm{mg} / \mathrm{kg}$, the order of Cd content in C. betacea seedlings was: root $>$ stem $>$ shoot > leaf, when the Cd concentration in soil was 10,15 and $20 \mathrm{mg} / \mathrm{kg}$, the order of Cd content in the organs of $C$. Betacea seedlings changede as: root $>$ leaf $>$ shoot $>$ stem. Under soil Cd concentration of $1,5,10,15$ and $20 \mathrm{mg} / \mathrm{kg}$, the Cd content in the roots was 1.91 times $(P<0.05)$, 20.26 times $(P<0.05), 21.21$ times $(P<0.05), 24.98$ times $(P<0.05)$ and 29.27 times $(P<0.05)$ respectively as much as that in the control, and the Cd content in the shoots was 1.90 times $(P<$ 0.05), 3.81 times $(P<0.05), 6.13$ times $(P<0.05), 8.89$ times $(P<0.05)$ and 11.22 times $(P<0.05)$ respectively as high as that in the control group. When the soil Cd concentration reached $20 \mathrm{mg} / \mathrm{kg}$, the Cd content was $168.86 \mathrm{mg} / \mathrm{kg}$ in the roots, $7.57 \mathrm{mg} / \mathrm{kg}$ in the stems, $8.59 \mathrm{mg} / \mathrm{kg}$ in the leaves and $8.08 \mathrm{mg} / \mathrm{kg}$ in the shoots. With the increase of soil Cd concentration, the TF of C. Betacea seedlings decreased first and then increased, and the $\mathrm{TF}$ of different soil $\mathrm{Cd}$ concentration treatments was less than 0.3 . Those results indicated that the $\mathrm{Cd}$ was mainly accumulated in the roots of $C$. Betacea seedlings, which could reduce the effect of $\mathrm{Cd}$ on the shoots of $C$. Betacea seedlings and was very beneficial to their growth.

Table 2 The Cd content in C. Betacea seedlings

\begin{tabular}{|c|c|c|c|c|c|}
\hline $\begin{array}{c}\text { Cd } \\
\text { concentration } \\
(\mathrm{mg} / \mathrm{kg})\end{array}$ & $\begin{array}{c}\text { Roots } \\
(\mathrm{mg} / \mathrm{kg})\end{array}$ & $\begin{array}{c}\text { Stems } \\
(\mathrm{mg} / \mathrm{kg})\end{array}$ & $\begin{array}{c}\text { leaves } \\
(\mathrm{mg} / \mathrm{kg})\end{array}$ & $\begin{array}{c}\text { Shoots } \\
(\mathrm{mg} / \mathrm{kg})\end{array}$ & TF \\
\hline 0 & $5.77 \pm 0.10 \mathrm{f}$ & $1.26 \pm 0.05 \mathrm{f}$ & $0.18 \pm 0.01 \mathrm{f}$ & $0.72 \pm 0.02 \mathrm{f}$ & 0.25 \\
\hline 1 & $11.05 \pm 0.27 \mathrm{e}$ & $2.12 \pm 0.15 \mathrm{e}$ & $0.62 \pm 0.02 \mathrm{e}$ & $1.37 \pm 0.09 \mathrm{e}$ & 0.25 \\
\hline 5 & $116.90 \pm 2.37 \mathrm{~d}$ & $3.05 \pm 0.10 \mathrm{~d}$ & $2.42 \pm 0.04 \mathrm{~d}$ & $2.74 \pm 0.07 \mathrm{~d}$ & 0.05 \\
\hline 10 & $122.40 \pm 2.74 \mathrm{c}$ & $3.64 \pm 0.12 \mathrm{c}$ & $5.17 \pm 0.03 \mathrm{c}$ & $4.41 \pm 0.08 \mathrm{c}$ & 0.07 \\
\hline 15 & $144.15 \pm 0.24 \mathrm{~b}$ & $5.72 \pm 0.07 \mathrm{~b}$ & $7.08 \pm 0.09 \mathrm{~b}$ & $6.40 \pm 0.01 \mathrm{~b}$ & 0.09 \\
\hline 20 & $168.86 \pm 3.39 \mathrm{a}$ & $7.57 \pm 0.06 \mathrm{a}$ & $8.59 \pm 0.07 \mathrm{a}$ & $8.08 \pm 0.00 \mathrm{a}$ & 0.10 \\
\hline
\end{tabular}

Different lowercase letters indicate significant differences based on one-way analysis of variance in SPSS 17.0 followed by the least significant difference test $(P<0.05)$.

\section{Conclusions}

C. Betacea seedlings did not show obvious toxic symptoms under the soil Cd concentration of 1 $20 \mathrm{mg} / \mathrm{kg}$. With the increase of soil Cd concentration, the root biomass, stem biomass, leaf biomass and shoot biomass of $C$. Betacea seedlings decreased gradually, the Cd content in the roots, stems, leaves and shoots increased significantly compared with the control. Moreover, the distribution of $\mathrm{Cd}$ in the stems and leaves of $C$. Betacea seedlings was different when they were under different soil $\mathrm{Cd}$ concentration. When the soil $\mathrm{Cd}$ concentration in soil was 0,1 and $5 \mathrm{mg} / \mathrm{kg}$, the order of $\mathrm{Cd}$ content in $C$. betacea seedlings was: root $>$ stem $>$ shoot $>$ leaf, when the Cd concentration in soil was 10,15 and $20 \mathrm{mg} / \mathrm{kg}$, the order of Cd content in the organs of $C$. Betacea seedlings was: root > leaf $>$ shoot $>$ stem. When the soil Cd concentration reached $20 \mathrm{mg} / \mathrm{kg}$, the Cd concentration of the roots was $168.86 \mathrm{mg} / \mathrm{kg}, 29.27$ times as much as that in control. As for the transport coefficient, the results showed that with the increase of soil $\mathrm{Cd}$ concentration, the TF of $C$. Betacea seedlings decreased first and then increased, and the TF of different soil Cd concentration was less than 0.3. These results showed that $C$. Betacea seedlings had low amplitude of biomass and strong absorption ability to $\mathrm{Cd}$ under the condition of low soil Cd concentration $(1-20 \mathrm{mg} / \mathrm{kg})$, and the Cd was mainly accumulated in the roots of $C$. Betacea seedlings, which could reduce the effect of $\mathrm{Cd}$ on the shoot of $C$. Betacea seedlings and is very beneficial to its growth. Therefore, $C$. Betacea seedlings had a strong tolerance to $\mathrm{Cd}$ stress. 


\section{Acknowledgements}

This work was financially supported by the Project of Sichuan Provincial Education Department (17ZB0342).

\section{References}

[1] Q.X. He: Environmental Science \& Technology Vol. 33(2013), p. 46.

[2] C.Y. Ma, D.J. Cai and H. Yan: Henan Chemical Industry Vol. 9(2013), p. 17.

[3] J.R. Guo: Shanxi Agricultural Science Vol. 63(2017), p. 13.

[4] J. Liang: Jiangsu Agricultural Science Vol. 43(2015), p. 110.

[5] X.F. Xiao, Q.W. Xie, L. Cai, M. Zhang and S.Y. Fan: Journal of Nuclear Agricultural Science Vol. 31(2017), p. 1864.

[6] J.Shi, R.P. Hu, L.L. Lin, T.Y. Huang, X.D. Zhu and C. Chun: Journal of Gansu Agricultural University Vol. 51(2016), p. 120.

[7] Editorial Committee of Chinese: Botany of the Chinese Academy of Sciences (Science Presss, Beijing, Chain 1986).

[8] J. He, L.L. Lin and J. Shi: Chinese Journal of Soil Science Vol. 5(2016), p. 1259.

[9] X. F. Zhang, H.P. Xia, Z.A. Li, Z. Ping and G. Bo: Journal of Hazardous Materials Vol. 189(2011), p. 414. 